\title{
Problematizations and Path Dependency: HIV/AIDS Policies in Denmark and Sweden
}

\author{
SIGNILD VALLGÅRDA*
}

\section{Introduction}

Problematization, or defining a phenomenon as a political problem, is a crucial step in any political process. It frames an issue as relevant and accessible to political action; it involves defining the nature of the problem, pointing to reasons for dealing with it, and identifying its causes as well as its possible solutions. In the words of Michel Foucault, "this transformation of a group of obstacles and difficulties into problems to which diverse solutions will attempt to produce a response, this is what constitutes the point of problematization". ${ }^{1}$ Foucault makes no mention of what is, in fact, a central component of problematization: namely, politicians or others perceiving the phenomenon as a "difficulty" worth dealing with. Problematization may encompass defining people with certain common features as a risk or target group, thereby placing them within reach of government. ${ }^{2}$ In political science the concepts of agenda setting and framing are used to describe central elements of the problematization process. In the political process of problematization, paths from previous political processes may be followed, not least when seeking solutions to the problem. Problematizations and path dependencies are interrelated in two ways: political paths influence what issues are perceived as problems and how they are perceived, and problematizations bring certain paths closer to hand. One might say that the choice of path, or path dependency, is an element of the problematization.

In most respects, Danish and Swedish policies toward HIV/AIDS have been similar, relying on information and education as the primary means for governing citizens' behaviour. There is, however, one crucial difference between the policies of the two countries, which has influenced researchers in their view of the countries' respective policies: namely, that the option of using coercive means against people who expose others to contagion has been introduced in Sweden, while this practice has not been enforced in Denmark. Why would countries that in other respects have fairly similar policies in the area of disease prevention and health advocacy, ${ }^{3}$ take different paths regarding the use of coercion in this issue? The answer is sought by addressing two questions: did the ways

\author{
(C) Signild Vallgårda 2007 \\ *Signild Vallgårda, MA, DMSc, Department of Health \\ Services Research, Institute of Public Health, \\ University of Copenhagen, Øster Farimagsgade 5, \\ 1014 Copenhagen K, Denmark; E-mail: \\ s.vallgarda@pubhealth.ku.dk \\ 1 'Polemics, politics, and problematizations: an \\ interview with Michel Foucault', in Paul Rabinow
}

(ed.), Ethics: subjectivity and truth / Michel Foucault, New York, New Press, 1997, pp. 111-19, p. 118.

${ }^{2}$ Nikolas Rose and Peter Miller, 'Political power beyond the state: problematics of government', Br. J. Sociol., 1992, 43: 172-205.

${ }^{3}$ Signild Vallgårda, Folkesundhed som politik. Danmark og Sverige fra 1930 til i dag, Århus, Aarhus Universitetsforlag, 2003. 


\section{Signild Vallgårda}

in which the issue was problematized contribute to explaining the differences in their respective policies? Did the way that Danish and Swedish politicians previously dealt with similar problems, i.e. well-trodden political paths, influence their choice of policy? HIV/AIDS is an interesting phenomenon to study, because it appeared on the political agenda almost simultaneously in the two countries and, as John Ballard states, "the novelty of AIDS makes it possible to discern precisely the processes of problematisation". 4

This article presents an analysis of legislation and debates in the parliaments of the two countries from the first mention of HIV/AIDS in these parliaments through the early 1990s. The focus is on the political ideas presented, not the implementation of actual policies. During the years of the major political debates (1980-87) 239 AIDS patients and 137 AIDS related deaths were registered in Denmark, while the corresponding numbers for Sweden were 159 and 79. Thus, the disease was rare, especially in Sweden where the population is almost twice that of Denmark.

Most analyses of AIDS policies consist of single-country studies. A systematic comparison may, however, shed light on factors not so easily observed when an isolated case is studied. The comparison of Danish and Swedish AIDS policies is motivated by their similarity, in many respects, regarding public health policies. This enables one to identify factors that may explain some differences (most similar system-model). ${ }^{5}$ The material studied consists of minutes from parliamentary debates, laws, and white papers.

\section{Danish and Swedish Strategies in HIV/AIDS Prevention}

The two main approaches to prevention of infectious diseases may be labelled containand-control strategy and cooperation-and-inclusion strategy. These were also followed in HIV/AIDS prevention efforts. ${ }^{6}$ The contain-and-control strategy implies "mandatory, compulsory examination and screening, breaching the confidentiality of the clinical relationship by reporting to public health registries the names of those with diagnoses of 'dangerous diseases'; imposing treatment; and, in the most extreme cases, confining infected persons through the power of quarantine". 7 In this way, the authorities attempt to govern citizens by appealing to the fear of sanctions such as isolation and compulsory treatment. ${ }^{8}$ This strategy has been pursued for centuries in policies aimed at infectious diseases in both Denmark and Sweden. ${ }^{9}$ In the cooperation-and-inclusion strategy, citizens are educated to behave responsibly. ${ }^{10}$ This could be described, with a nod to Michel

\footnotetext{
${ }^{4}$ John Ballard, 'The constitution of AIDS in Australia: taking "government at a distance" seriously', in Mitchell Dean and Barry Hindess (eds), Governing Australia: studies in contemporary rationalities of government, Cambridge University Press, 1998, pp. 125-38, p. 126.

${ }^{5}$ Theda Skocpol, Margaret Somers, 'The uses of comparative history in macrosocial inquiry', Comp. Stud. Soc. Hist., 1980, 22: 174-97.

${ }^{6}$ Ronald Bayer and David L Kirp, 'Introduction', in David L Kirp and Ronald Bayer (eds), AIDS in the industrialized democracies, New Brunswick, Rutgers University Press, 1992, pp. 4-5.
}

\footnotetext{
${ }^{7}$ Donald L Kirp and Ronald Bayer, 'The second decade of AIDS: the end of exceptionalism?', Kirp and Bayer (eds), op. cit., note 6 above, pp. 361-84, p. 364.

${ }^{8}$ Signild Vallgårda, 'Studier af magtud $\varnothing$ velse. Bidrag til en operationalisering af Michel Foucaults begreb governmentality', in Peter Munk Christiansen and Lise Togeby (eds), På sporet af magten, Århus, Aarhus Universitetsforlag, 2003, pp. 117-31.

${ }^{9}$ Vallgårda, op. cit., note 3 above, ch. 4.

${ }^{10}$ Kirp and Bayer, op. cit., note 7 above, pp. 364-5.
} 


\section{HIV/AIDS Policies in Denmark and Sweden}

Foucault, as "conduct of conduct", whereby people are governed in such a way that they choose to behave according to the goals of those attempting to govern (for example, the authorities). His point is that technologies of domination are combined with technologies of the self. ${ }^{11}$

As in many other countries, both strategies had advocates in Denmark and Sweden regarding HIV/AIDS. ${ }^{12}$ While Danish politicians chose to follow the cooperation-andinclusion approach only, the Swedes incorporated both strategies in their HIV/AIDS prevention policies.

In Sweden, HIV/AIDS was simply added to existing legislation on infectious diseases, which also encompassed venereal diseases; in Denmark it was not. Denmark abolished its legislation on venereal diseases in June 1988, partly in response to the emergence of HIV/ AIDS, but left legislation on other infectious diseases practically unchanged. The legislation on venereal diseases was counterproductive, it was argued, because its potentially stigmatizing effect would lead people to refrain from seeking diagnosis and treatment from public health services. The Danish National Board of Health ruled that the law had no effect and that, "only through extensive education and information with the option of anonymity is it possible to motivate persons who think they may be infected to see a doctor". ${ }^{13}$ Since then, venereal diseases have not been subject to legislative controls in Denmark. Erik Albæk argues persuasively that HIV/AIDS was treated with much greater caution and sensitivity than other venereal diseases traditionally had been. ${ }^{14}$ The cautious treatment of HIV/AIDS even resulted in a more sensitive treatment of other venereal diseases as the law was abolished. Specific rules relating to HIV/AIDS about doctor/patient confidentiality were introduced, however. According to instructions from the National Board of Health in 1992, this could be breached in the event that a child was exposed to possible infection. ${ }^{15}$ Incidences of AIDS and HIV-infection were to be reported to the authorities. ${ }^{16}$ According to a memo dated 25 June 1990, reports about persons diagnosed as HIV-positive were to be made anonymously.

HIV/AIDS was incorporated into the Swedish law on infectious diseases in 1985. The law did, as already mentioned, include the possibility of compulsory treatment and isolation. In 1988, a new law concerning infectious diseases was passed, chiefly because of HIV/AIDS. This law enabled the authorities to use compulsory examination

\footnotetext{
${ }^{11}$ Michel Foucault, 'The subject and power. Why study power: the question of the subject: how power is exercized', in Hubert L Dreyfus and Paul Rabinow (eds), Michel Foucault: beyond structuralism and hermeneutics, Brighton, Harvester Press, 1982, pp. 208-26; 'Technologies of the self: a seminar with Michel Foucault', in Luther H Martin, Huck Gutman, Patrick H Hutton (eds), Technologies of the self, Amherst, University of Massachusetts Press, 1988, pp. 16-49.

${ }^{12}$ On other countries, see Kirp and Bayer (eds), op. cit., note 6 above; Daniel M Fox, Patricia Day, Rudolf Klein, 'The power of professionalism: policies for AIDS in Britain, Sweden, and the United States', Daedalus, 1989, 118, no. 2: 93-112; Stanislaw Frankowski (ed.), Legal responses to AIDS in
}

comparative perspective, The Hague, Kluwer Law International, 1998

13 ،... at man kun gennem massiv oplysning og information med mulighed for anonymitet kan motivere personer, der er eller tror sig smittet, til at søge læge". Folketingstidende 1987-88.

${ }^{14}$ Erik Albæk, 'Denmark: AIDS and the political "pink triangle", , in Kirp and Bayer (eds), op. cit., note 6 above, pp. 281-316.

${ }^{15}$ Sundhedsstyrelsens redegфrelse til Indenrigsministeriet vedrorende initiativer $i$ bekcompelsen af AIDS, Copenhagen,

Sundhedsstyrelsen, 1987, p. 40; Vejledning om human immundefekt virus HIV og forebyggelse af blodbåren smitte, Copenhagen, Sundhedsstyrelsen, 1992, p. 23.

${ }^{16}$ Bekendtgørelse om lægers anmeldelse af erhvervet immundefekt syndrom, 8. november 1985. 


\section{Signild Vallgårda}

and isolation. ${ }^{17}$ Compulsory examinations were not, however, to involve any major physical intervention. The new law explicitly prohibited compulsory treatment: it required infected individuals to inform the doctor of possible sources of infection, but prescribed no sanctions against those who refused to do so. In other words, all penalty clauses were removed from the law. In 1986 it was decided that central health officials should be notified of only the first two and the last four digits in a patient's social security number, address, and potential risk group, thereby making it almost impossible to identify the person. ${ }^{18}$ Another restrictive law was passed in Sweden in 1987, making sauna clubs illegal. The intention was to prevent men who engage in sexual activity with men from using these clubs as meeting places. ${ }^{19}$ In Denmark such clubs were not closed, but used as a means of reaching this population with information and condoms.

In Denmark, therefore, HIV/AIDS was not included in the laws on venereal and infectious diseases, and the law on venereal diseases was abolished as a result of political reactions to HIV/AIDS. Danish politicians thus rejected the contain-and-control strategy in efforts to prevent the spread of HIV/AIDS. In Sweden, by contrast, HIV/AIDS was included in the law on infectious diseases. The law was changed following the debates on HIV/AIDS, allowing the continued use of isolation, but not compulsory treatment, and all penalty clauses were removed. Swedish politicians thus made use of the contain-andcontrol strategy in preventing the spread of HIV/AIDS in addition to the cooperation and inclusion strategy.

\section{What was the Problem?}

In the following section, the debate on HIV/AIDS prevention in the two parliaments will be analysed, in order to identify how the issues were problematized. The delineation of risk groups was crucial to the political paths followed. From the very first political discussions about HIV/AIDS, the most prevalent identified risk groups were identical in the two countries: namely, men who have sex with men, and intravenous drug users (IVDUs). But politicians disagreed, first, in their estimation of the magnitude of the problem; second, in the way they defined and emphasized the role of these risk groups; and third, in their perception of the risk of spreading infection to other population groups.

\section{Denmark}

In the Danish parliament (Folketinget), issues pertaining to gay men and their risk of contracting HIV dominated the debate. In 1987, a political majority voted overwhelmingly in favour of recommending efforts towards "free will, anonymity, open, direct and honest information; trust in the individual turning to health authorities on his own, and the distinct

\footnotetext{
${ }^{17}$ Regeringens proposition 1988/89:5 med förslag om ny smittskyddslag m.m. 18 augusti 1988, p. 27, Riksdagstryck 1988/89.

${ }^{18}$ Regeringens proposition med förslag om vissa ändringar i sekretessreglerna för effektivare
}

insatser mot spridningen av LAV/HTVL-III, 1986/87:2, p. 13.

${ }^{19}$ SFS 1987: 375. Lag om förbud mot s.k. bastuklubbar och andra liknande verksamheter. 


\section{HIV/AIDS Policies in Denmark and Sweden}

desire to avoid any kind of discrimination". ${ }^{20}$ The formulation clearly rejected the use of coercion. The emphasis on avoiding discrimination indicates that members of parliament primarily had homosexual men in mind-not IVDUs. This position was also evident in the debates: politicians repeatedly expressed a wish to avoid discrimination against gay men, and voiced confidence that this group would act responsibly.

The Danish infectious disease law allowed for the addition of specified diseases, but Danish politicians did not choose to include HIV/AIDS under that dispensation. Coercive means were considered both inefficient and a potential source of discrimination. In 1987, the Social Democrat MP Henning Rasmussen stated in parliament that, "any premonition that there could be a risk that they will be registered, or that any kind of coercive measures might be used against them, will lead to certain catastrophe in transmitting the contagion, just as it will lead to discrimination and special treatment to a degree that none of us cares for". ${ }^{21}$ Another reason was that politicians perceived HIV/AIDS to be different from many other infectious diseases: "one does not risk becoming infected with the disease against one's will" as the Conservative MP Karen Højte Jensen observed in $1985 .^{22}$ This attitude was voiced by several politicians. One possible objection to this argument could be that individuals raped by an HIV-positive person, babies born to infected mothers and those infected through the use of blood products have no possibility of defending themselves.

The policy adopted by the majority in parliament involved governing through appeals to, and the shaping of, responsibility. Dorte Bennedsen, a Social Democrat MP, expressed confidence in the gay community: "Gay men in Denmark have shown an incredibly responsible attitude precisely because we have given them the secure conditions we have in this country." 23 Agreement on this issue ran right across the spectrum of Danish politics. As the Liberal Party MP Anders Mølgaard noted: "Currently, there is no alternative to strong personal responsibility - this principle is simply key—a maximum sense of responsibility on the part of the individual for his or her own life and health, as well as that of others." ${ }^{24}$ In order for AIDS prevention efforts to be based on a principle of voluntary cooperation, citizens had to be motivated to behave responsibly. This would be achieved through education and by attempting to shape people's desires. In 1987, the Liberal Minister for the Interior, Knud Enggaard, argued that prevention was to be achieved by "information and education, with the expectation of motivating and

20 “... frivillighed, anonymitet, åben, direkte og ærlig information, den enkeltes tryghed ved at henvende sig til sundhedsmyndighederne, samt $\varnothing$ nsket om at undgå enhver form for diskrimination".

Folketingstidende 1986/87.

21 “... . enhver tanke om, at der kan være risiko for, at de bliver registreret, eller at der bliver anvendt en eller anden form for tvangsforanstaltninger over for dem, fører til en katastrofe med hensyn til smittespredning, ligesom det åbner vejen for diskrimination og forskelsbehandling i en grad, som ingen af os bryder os om." Folketingstidende 1986/87, column 9856.

22 “. . . man risikerer ikke at blive påført sygdommen mod sin vilje”. Folketingstidende 1985/ 86, column 3052 .

\footnotetext{
23 "Bøsserne i Danmark, som har vist en utrolig ansvarlig holdning, netop fordi vi har sikret dem de vilkår, vi har her i landet." Forslag til Lov om registrering af AIDS-syge og HIV-positive fremsat af FP 1. februar 1991. Folketingstindende 1990-91, column 2420.

24 “"Aktuelt findes der intet alternativ til en stærk personlig ansvarlighed-dette princip er simpelt hen nøglen —en maksimal ansvarsfølelse hos det enkelte menneske for sit eget og sine medmenneskers liv og helbred." Forslag til Lov om registrering af AIDS-syge og HIV-positive fremsat af Fremskridtspartiet 1. februar 1991. Folketingstidende 1990-91, Anders Mølgård, column 2415.
} 


\section{Signild Vallgårda}

instigating necessary changes in lifestyle habits". ${ }^{25}$ Education was regarded as practically the sole means of prevention, and it was continuously reiterated on the floor of parliament that gay organizations played a central role in AIDS education and counselling. The government also granted these groups financial support to carry out this task: in other words, it was a strategy of cooperation and inclusion, using information and education as primary resources.

The liberal Danish policy was not considered to be without problems, however. Drug addicts represented a group that could not easily be governed through appeals to responsibility. In 1987, the Conservative MP Grethe Fenger Møller stated: “As long as abusers lack responsibility and care for themselves, they will neither be motivated nor capable of protecting themselves." 26 The political goal was therefore to establish responsibility. According to Knud Enggaard, drug addicts would be "helped to a better life, a life in which they feel a sense of responsibility for themselves and others". The challenge was rendering the right choices easy to make, especially for drug addicts, by giving them "easy access to disposable syringes and hypodermic needles, and easy access to treatment". ${ }^{27}$ Similarly, in that year the National Board of Health recorded that "a particular effort must be made in the field of drug abuse, which is the greatest threat of transmitting contagion in the heterosexual segment of the population-and the most difficult to do anything about". ${ }^{28}$ The promotion of more cautious behaviour, as well as a cure for drug addiction, was suggested. It was a policy that implied an active role for the authorities, but not coercion.

\section{Sweden}

The Swedish conception of at risk groups for Aids/HIV infection was broader than the Danish. Here attention focused on "intravenous drug users, homosexual and bisexual men, customers of prostitutes, persons with multiple sexual partners, and young girls in close contact with drug abusers, etc." ${ }^{29}$ The proportion of AIDS cases occurring between 1982 and 1990 in the two primary risk groups were similar in both countries. In Denmark, 75 per cent were infected by same-sex activities and 4 per cent were drug-users, while in Sweden the figures were 72 per cent and 3 per cent. ${ }^{30}$ The fear of transmission outside the delineated risk groups was more pronounced in Sweden than in Denmark and was a central

\footnotetext{
25 “... information og oplysning med henblik på motivation og tilskyndelse til de nødvendige ændringer i livsvanerne". Folketingstidende 1986/87, column 9811.

26 "Så længe misbrugeren mangler ansvarlighed og omsorg for sig selv, så længe er han eller hun ikke motiveret for at beskytte sig selv og overvejer heller ikke at beskytte andre og er vel i virkeligheden heller ikke i stand til det". Folketingstidende 1986/87, column 9825.

27 “. . . hjælpes til et bedre liv, et liv, hvor de føler ansvar over for sig selv og for andre" "let adgang til engangssprøjter og kanyler og let adgang til behandling". Folketingstidende 1986/87, column 9811.
}

\section{8 ، .. . en særlig indsats må gøres på} stofmisbrugsområdet, som er den største trussel for videre smittespredning i den heteroseksuelle befolkning —og det mest vanskelige at gøre noget ved". Sundhedsstyrelsens redegфrelse, op. cit., note 15 above, p. 5.

29 “. . . intravenösa narkotikamissbrukare, homooch bisexuella män, kunder till prostituerade, personer med många sexualpartner och unga flickor som har nära kontakt med narkotikamissbrukare m.fl." Regeringens proposition 1987/88:79 om åtgärder mot AIDS, p. 23.

${ }^{30}$ Albaek, op. cit., note 14 above, p. 288; Benny Henriksson and Hasse Ytterberg, 'Sweden: the power of the moral(istic) left', in Kirp and Bayer (eds), op. cit., note 6 above, pp. 317-38, on p. 320. 


\section{HIV/AIDS Policies in Denmark and Sweden}

reason for the pronounced political interest in IVDUs and IVDU prostitutes. In a private members bill of 1986-87, the Agrarian Liberal Party stated: "The fact that the HIV virus is being transmitted to new groups through prostitution is particularly grave." 31 Swedish politicians in general seemed more alarmed by the disease, referring to it as "the plague of our time" 32 and employing military imagery when describing the threat to public health. In 1986, the Social Liberal Party wrote, "[a]n effective general headquarters must be established to lead efforts to fight HTVL-III and AIDS ... A massive, international counterattack is necessary." 33 It was stressed more frequently in Sweden than in Denmark that the key challenge was to prevent the spread of the virus among heterosexuals. Conditions for homosexual and bisexual men were less central to the debate. This difference from Denmark may indicate a lesser degree of respect or tolerance for homosexuals. So, too, might the prohibition of sauna clubs. On the other hand, the lack of attention devoted to contagion among gay men may denote an understanding that, thanks to the behaviour of the homosexuals themselves, the problem was under control. The Swedish parliament's Social Welfare Committee argued that RFSL (The National Union for Sexual Equality) "is currently the best channel for reaching homosexuals. It was also active in informing their membership several years before the National Board of Health and Welfare." 34 The gay rights organization was believed to have shown a high degree of responsibility, and the need to govern the behaviour of gays was therefore considered largely insignificant. The government argued that HIV-positive persons "to a great extent [showed] readiness to adapt their lifestyles", but that "concerning IVDUs, the experience is less positive". ${ }^{35}$ Special measures relating to drug abusers such as diagnosis, detoxification and addiction treatment were therefore taken in order to prevent dissemination of the disease inside, as well as outside, the IVDU community. ${ }^{36}$ The distribution of clean disposable syringes, organized by certain Danish counties, was also debated in Sweden. Permission was granted for an experiment involving the distribution of clean syringes in the towns of Malmö and Lund. This experiment was still running in 2003, but had not been adopted by any other Swedish cities. The government argued that an initiative of this kind would send the wrong signals: that by dispensing "free syringes and needles, confidence in narcotics policies would be weakened". ${ }^{37}$ Sweden's more restrictive drug policy made the political option of enforcing responsible behaviour among IVDUs less attractive. The preferred strategy was to make them stop using drugs altogether. The political focus

\footnotetext{
31 “Särskilt allvarligt är att HIV-virus genom prostitutionen överförs till nya grupper." Motion 1986/87: So 437, Riksdagstryck 1986/87.

32 “... vår tids pest”. Motion 1985/86: So 429, Riksdagstryck 1985/86.

33 "Effektivt högkvarter inrättas för att leda arbetet mot HTVL-III och aids ... Det behövs nu en massiv och internationell motattack." Motion 1985/86: So 416, Riksdagstryck 1985/86.

34 "RFSL, Riksförbundet för sexuellt likaberättigande, är i dag den bästa kanalen ut till de homosexuella. De var också ute flera år tidigare än socialstyrelsen med att informera sina medlemmar
}

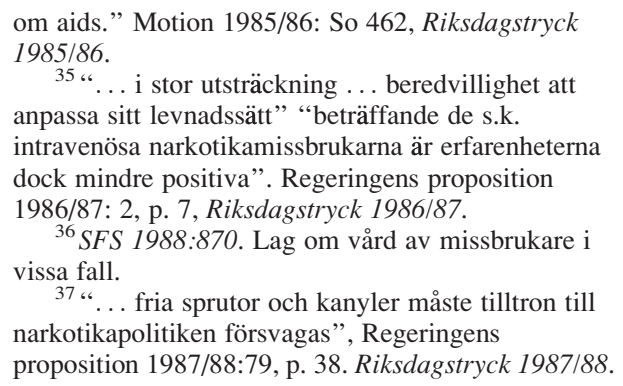




\section{Signild Vallgårda}

on IVDUs was also clear from the descriptions of the restrictive measures to be used against isolated individuals. These included, for example, prohibiting the possession of alcohol, drugs, and syringes "and other paraphernalia applicable in the use or abuse of drugs". ${ }^{38}$ The compulsory isolation of HIV-positive people was clearly intended for the IVDUs risk group.

Like the Danes, Swedish politicians envisaged governing gay men through appeals to responsibility. Compulsion was intended only for citizens who could not be controlled through such means: "The few individuals who are not prepared to take their responsibility seriously, must, however, be brought into line by compulsion." 39

The coercive measures introduced in Sweden were thus aimed at a minority of just one risk group. As with Denmark, Sweden's main strategy was to appeal to the individual's sense of responsibility through education and cooperation. In 1988, the Social Democratic Minister of Social Affairs stated: "I will, however, emphasize that transmission can, with very few exceptions, be progressively prevented by voluntary means." On the same occasion, he stressed that it was not solely the individual who was responsible: "It is not simply individuals who have responsibilities regarding disease control; society must take responsibility for these individuals, as well, if disease protection is to enjoy the public's confidence." 40 The more frequent emphasis on government's own social responsibility in Sweden than in Denmark is characteristic of public health policy in general. Compared to Denmark, less emphasis is placed on individual lifestyles and more on living conditions and social relations. $^{41}$

The apparent greater alarm over HIV/AIDS among Swedish politicians than among their Danish counterparts may have been due to this view of Sweden as a country where major health problems, especially infectious diseases, had been long under control before the advent of HIV/AIDS. When describing the results of public health policy and the policy of the welfare state in general, politicians repeatedly expressed considerable complacency. ${ }^{42}$ The arrival of a new and uncontrollable infectious disease was, consequently, upsetting. The more alarmed reaction towards the disease may help to explain why coercive methods were incorporated into Swedish legislation.

The problematization of HIV/AIDS infection in the Danish and Swedish parliaments differed, both with regard to how risk groups were defined, and, more particularly, to the groups given most attention. Danish and Swedish politicians also differed in the emphasis given to the likelihood of infection spreading outside the identified risk groups, and the degree of fear this risk seemed to unleash.

\footnotetext{
38 ، ... andra föremål som är särskilt ägnade att användas för missbruk av eller annan befattning med narkotika”, SFS 1988: 1472 Smittskyddslag.

39 ، . . . de få människor som inte är beredda att ta sitt ansvar måste däremot tvång kunna tillämpas". Motioner till riksdagen 1987/88: So4, Riksdagstryck $1987 / 88$.

40 “Jag vill dock understryka attsmittspridning, med få undantag, framgångsrikt kan förhindras med frivilliga åtgärder." "Inte endast de enskilda
}

människorna har skyldigheter inom smittskyddet, också samhället måste ha skyldigheter mot de enskilda människorna om smittskyddet skall kunna åtnjuta medborgarnas förtroende." Regeringens proposition 1988/89: 5, p. 27. Riksdagstryck 1988/89.

${ }^{41}$ Vallgårda, op. cit., note 3 above, ch. 6.

${ }^{42}$ Ibid., pp. 133ff. 


\section{HIV/AIDS Policies in Denmark and Sweden}

\section{Paths}

HIV/AIDS was perceived in both countries as an infectious disease that could be transmitted sexually and through blood, and which mainly affected men who had sex with men, and intravenous drug users. In this section I will discuss policies concerning infectious and venereal diseases, as well those directed towards the two communities defined as primary risk groups, in order to identify the paths followed by the policies dealing with the new disease.

\section{Policies on Infectious Diseases}

Legislation on infectious and venereal diseases was introduced as early as the late eighteenth century in Denmark, and approximately a hundred years later in Sweden. In the early twentieth century, the legislation was almost identical in the two countries, and remained so until the 1980s. The laws implied registration and infection tracing, and allowed for compulsory treatment and isolation. In Denmark, a new law on infectious diseases was passed in 1979 and, a series of small changes in 1994 notwithstanding, that law is still in force today.

The basic provision enshrined in the law is that a person infected with a common dangerous disease must seek medical attention and be hospitalized, if necessary. If the person does not comply voluntarily, compulsion may be used. The law includes a list of diseases classified as commonly dangerous, and allows the Minister of the Interior to order compulsory treatment. The law also obliges all citizens to alert the relevant authorities if they are aware of any person suffering from a general infectious disease. ${ }^{43}$ By and large, the 1973 law on venereal diseases imposed the same obligations. Deliberately exposing other people to infection was punishable by law. ${ }^{44}$ Furthermore, tracing sources of infection was mentioned, but not regulated. The Swedish law current when HIV/ AIDS became the object of political attention dated from 1969, and covered both infectious and venereal diseases. Like the Danish law, it made compulsory examination and compulsory treatment possible. It also included the public's duty to inform the authorities of persons infected with an infectious disease. Swedish doctors were to report all cases of persons suffering from infectious diseases along with the person's personal data. The Swedish law included more diseases than the Danish one, but was otherwise virtually identical.

There is therefore not much to be found in the history of legislation on infectious and venereal disease prior to the early 1980s that may explain the differences in HIV/AIDS policies. Yet, in spite of the similarities, there have been some differences in policy towards specific infectious diseases over the last two centuries. Could these help to explain the differences in the present policies?

Peter Baldwin's recent study of AIDS policies in several countries includes Sweden, but not Denmark. Baldwin seeks to explain "broad and drastic interventions" adopted by Sweden. In describing Swedish policy, he focuses almost exclusively on the compulsory

\footnotetext{
${ }^{43}$ Lov om foranstaltninger mod smitsomme sygdomme, 21. Marts 1979.
}

\footnotetext{
${ }^{44}$ Lov om bekæmpelse af kønssygdomme. 23 May 1973.
} 


\section{Signild Vallgårda}

measures, omitting the other strategies additionally employed by Swedish politicians. His argument is that path dependency has structured public health policy and that today's measures against HIV/AIDS can be traced back to nineteenth-century political attitudes towards infectious diseases, such as cholera, for which Sweden had a very protectionist strategy, namely quarantine. ${ }^{45}$ Peter Baldwin's explanation has the beauty of simplicity. The Swedish policy is seen only as coercive, following a path from the nineteenth-century contagious disease policies particularly that against cholera. The cholera example may be misleading, however. It may, perhaps, be more pertinent to study measures against tuberculosis in the first half of the twentieth century. ${ }^{46}$ Not only is this example historically closer in time, but tuberculosis has important similarities to AIDS. Unlike cholera, which was imported, tuberculosis was an endemic disease. Like AIDS, tuberculosis more often affected young and middle-aged people, it was often chronic, and frequently fatal. It mainly affected a limited segment of the population (the poor), but the risk of contagion, as with AIDS, existed for most of the population. There are, of course, also important differences between the two diseases. AIDS may be transmitted sexually, and the number of people affected in the two Scandinavian countries was low. As mentioned above, only a few hundred people were infected with HIV/AIDS during the years 1980-87, while the number of deaths due to tuberculosis in a single year, 1930, was 2472 in Denmark and 7715 in Sweden. Again, the authorities thought they had a cure for tuberculosis in the early twentieth century, albeit not a very effective one; no known cures were available for AIDS. In any case, tuberculosis has many more similarities with AIDS than does cholera and other acute infectious diseases of the nineteenth century, and its policies date back seventy to 100 years, not 150 . What was the attitude of Danish and Swedish politicians towards tuberculosis, and were their reactions similar to politicians' responses towards HIV/AIDS?

They reacted differently. In Denmark, tuberculosis was included in legislation on infectious diseases as early as 1897, and in 1905 and 1912 special legislation allowing for compulsory isolation, compulsory treatment and registration as well as free care was passed. Such extensive enactments were never passed for tuberculosis in Sweden. Legislation in 1939 included registration and compulsory testing but not compulsory treatment and isolation. Swedish politicians considered the use of compulsory measures potentially stigmatizing, and believed that it would be counterproductive in limiting the spread of the disease: that is to say, they used the same arguments that Danish politicians employed to argue against coercive methods for HIV/AIDS. The paths from the tuberculosis policies were therefore not subsequently followed for HIV/AIDS. If that had been the case, there would have been less use of force in preventing HIV/AIDS in Sweden than in Denmark. It is possible, of course, that Danish politicians found their experience in using compulsory treatment for tuberculosis prejudicial, and consciously opted against it for HIV/AIDS. It is more likely, however, that policies on tuberculosis had no influence on policies for HIV/AIDS - that the paths were deleted. There was no straight line in policies

\footnotetext{
${ }^{45}$ Peter Baldwin, Disease and democracy: the industrialized world faces AIDS, Berkeley, University of California Press, 2005, pp. 251, 244.
}

\footnotetext{
${ }^{46}$ Vallgårda, op. cit., note 3 above, ch. 4.
} 


\section{HIV/AIDS Policies in Denmark and Sweden}

on infectious diseases from tuberculosis to AIDS, and it seems even less likely that nineteenth-century policies on diseases such as cholera would shape late-twentieth-century policies on HIV/AIDS. In order to constitute part of a political problematization, a political path probably must be recently trodden. Political memoires are short, political contexts change. Paths from seventy or 150 years back do not form an immediate frame of reference for today's policy-makers. What, then, could be the reason for the difference between HIV/ AIDS policies in the two countries?

\section{Policies towards Gay People and Drug Abusers}

One possible explanation might be that Denmark had a more liberal policy towards homosexuals. Yet, the attitude towards homosexuals seems to have been more or less the same in both countries, even if Denmark introduced legislation granting equal rights to gays and heterosexuals slightly earlier than Sweden. ${ }^{47}$ The introduction of the same age of consent was passed in 1976 in Denmark and 1978 in Sweden, equal rights for homosexual and heterosexual cohabitors in 1986 and 1987 for Denmark and Sweden respectively, and registered partnership in 1989 and 1994 respectively. ${ }^{48}$ Most of these laws were introduced after HIV/AIDS had reached the political agenda. HIV/ AIDS thus did not lead to more restrictive legislation towards homosexuals. The emergence of the disease may, if anything, have been conducive to legislation granting homosexuals and heterosexuals a higher degree of equality. Homosexuals had wellestablished organizations in both countries (Riksförbundet för sexuellt likaberättigande and Landsforeningen for bøsser og lesbiske). The Danish organization was created in 1948, the Swedish in 1950. The Swedish organization became a collaborative partner of the authorities somewhat earlier than the Danish. Gay rights organizations were incorporated into HIV/AIDS information and education efforts in both countries and were considered responsible partners in the fight against the disease. With the exception of the sauna club law, it is impossible to find differences in the attitudes towards homosexual and bisexual men that might explain the differences between the two countries.

Drug abusers were another social group with a high rate of infection. In Denmark and Sweden, IVDU prostitutes were considered the most likely conduit for spreading the virus to other heterosexual groups. Regarding IVDUs, the difference in legislation between the two countries has been much more distinct. In Sweden, there is a long tradition of compulsory treatment for substance abusers, firstly alcoholics, later drug addicts. Legislation on the compulsory treatment of alcoholics dates back to 1913. The motive for compulsion was the safety of others, but a 1931 revision also stressed the need for care of the abusing individual. During the 1950s and 1960s voluntariness was more prominent, but in 1980 compulsion was again tightened up and even more so from

\footnotetext{
${ }^{47}$ Albæk, op. cit., see note 14 above, pp. 283, 284-5; Henriksson and Ytterberg, op. cit., note 30 above, p. 321.
}

\footnotetext{
${ }^{48}$ From 1 January 2003 officially registered homosexual couples are allowed to adopt children in Sweden. No corresponding law has been passed in Denmark.
} 


\section{Signild Vallgårda}

1989. ${ }^{49}$ Reasons for use of compulsion was both that the individual would benefit from the treatment, and that he or she might harm him- or herself or others. In Denmark compulsory treatment of alcoholics also was introduced under various laws in the early twentieth century, mainly motivated by protection of others. By 1933 compulsion was justified by failure to support a family. Gradually, however, the voluntary principle emerged, and in 1976 the compulsory treatment of alcohol and drug abusers was abolished. ${ }^{50}$ Thus the two countries moved in opposite directions: Sweden towards more compulsion, Denmark towards less. Where drug abusers were concerned, the policy paths were quite different in the 1980s, and they led in different directions.

If the path from the policies toward gay people was influencing HIV/AIDS-policy, we would not expect differences between the two countries. The policy towards drug-users was, however, quite different. The contain-and-control strategy which had for so long been established in Sweden was abandoned in Denmark.

\section{Public Health Policies in other Fields}

On the basis of this case study, it might be concluded that the contain-control strategy had been abandoned in Danish public health policy in general, while that was not the case in Sweden. The degree and extent of social regulation in the two countries is beyond the scope of this article, but in respect of public health policy generally, the picture is unclear. In some areas, above all relating to alcohol, Swedish regulation is much more restrictive than Danish and has been so for the past century. The alcohol policy in particular has contributed to the view that Swedish policy is more restrictive, an interpretation which has been widely accepted, not least in Denmark. ${ }^{51}$ Where the mentally ill are concerned, for example, provision was almost identical in the two countries. Compulsion could be used both for the sake of the patient and to prevent harm to others; ${ }^{52}$ the same arguments that were put forward to justify using compulsion against substance abusers in Sweden. Other public health initiatives, such as health screening for children and pregnant women, were introduced simultaneously and have been almost identical, with the exception that school

\footnotetext{
${ }^{49}$ Arne Kinnunen, 'Den bristande motivationen. En litteraturstudie över tvångsvård av rusmedelsemissbrukare i de nordiska länderna', in Astrid Skretting, Margaretah Järvinen and Lena Hübner (eds), Missbruk och tvångsvård, Helsingfors, Nordiska nämnden för alkohol- och drogforskning, 1994, pp. 33-108; Lena Hübner, Missbruk och tvångsvård: de nordiska ländernas lagstiftning om vård av missbrukare utan eget samtykke, Stockholm, Nordiska kontaktmannaorganet för narkotikafrågor, 1991, p. 2; Jenny Björkman, Vård för samhällets bästa. Debatten om tvångsvård $i$ svensk lagstiftning 1850-1970, Stockholm, Carlssons, 2001; Sven-Ake Lindgren, Den hotfulla njutningen. Att etablera drogbruk som samhällsproblem 1890-1970, Stockholm, Symposium Graduate, 1993; Sidsel Eriksen, 'Drunken Danes and sober Swedes. Religious revivalism and the temperance movements as keys to Danish and Swedish folk cultures', in Bo Stråth (ed.), Language and the
}

construction of class identities: the struggle for discursive power in social organisation. Scandinavia and Germany after 1800, Gothenburg University, 1990, pp. 55-94.

${ }^{50}$ Kinnunen, op. cit., note 49 above, pp. 94-7; Thorkil Thorsen, Dansk alkoholpolitik efter 1950, Holte, SOCPOL, 1993, pp. 133-6, 213-16.

${ }^{51}$ Albæk, op. cit., note 14 above, pp. 282-3, 292; Erik Albæk, 'Holy smoke, no more? Tobacco control in Denmark', in Eric A Feldman and Ronald Bayer (eds), Unfiltered: conflicts over tobacco policy and public health, Cambridge, MA, Harvard University Press, 2004, pp.190-218, esp. p.193; Baldwin, op. cit., note 45 above, p. 151.

${ }^{52}$ Hübner, op. cit., note 49, pp. 10-11, 41. 


\section{HIV/AIDS Policies in Denmark and Sweden}

health examinations were compulsory for several decades in Denmark. ${ }^{53}$ In regard to tobacco policy, the tendency in both countries has been towards more regulation, although this has been weaker in Denmark than elsewhere. ${ }^{54}$ Compulsory provision for motor cycle helmet and seat belt use exists in both countries and in Denmark pedestrians are forbidden to cross the street when pedestrian lights are red. There is thus no clear picture indicating a general path in public health policy towards regulation or voluntariness in either country; Denmark and Sweden differ depending on the policy area studied. During the twentieth century there has been a general tendency in both countries for the authorities to intervene more in the lives and behaviour of their citizens in order to achieve a good and healthy life ${ }^{55}$ and in both countries citizen attitudes to the state seem to be rather that it is a benefactor than the opposite. One cannot infer a dominating tendency in the general public health policy from AIDS policies, nor vice versa.

\section{Conclusion}

Two governing strategies have dominated attempts to prevent the transmission of infectious diseases in Sweden and Denmark, namely appeals to responsibility and appeals to fear of sanctions, compulsory examination and compulsory isolation; these strategies also applied to HIV/AIDS. Politicians in both countries have emphasized the cooperationand-inclusion strategy, in which the central principle was to encourage people to act responsibly towards their fellow citizens. The Swedes did not rely exclusively on this tactic, however. The possibility of using coercion and registration against HIV-positive persons who exposed others to contagion was also used in Sweden. Why did Swedish politicians choose to use methods of compulsion while the Danes did not? The path of the countries' respective policies on other infectious diseases does not seem to have been influential - at any rate, it fails to explain the differences between Denmark and Sweden, since they both previously had almost identical policies in this area, except that for tuberculosis where Denmark relied more on the contain-and-control strategy. Substantial differences in attitudes and legislation toward gay people which might explain the harsher Swedish policy do not seem to exist. Differences between the two countries have, however, been identified, both in the ways that HIV/AIDS was problematized and in the political paths followed. In Denmark, politicians discussed HIV/AIDS mainly as a gay man's disease, and liberal, anti-discriminatory policies towards homosexuals were therefore decisive in policy selection. In Sweden, a different way of problematizing the issue may be observed, with politicians appearing more alarmed by the disease, and paying greater attention to the dissemination of HIV/AIDS to new social groups, identifying drug addicts and prostitutes as the biggest problem. Unlike Denmark, Sweden had a long and increasingly strong tradition for the compulsory treatment of drug addicts. Hence, the restrictive policy towards drug addicts may have been the path followed, also in preventing HIV/AIDS transmission to people outside the identified risk groups, of which IVDUs were

\footnotetext{
${ }^{53}$ Vallgårda, op. cit., note 3 above, chs 3 and 9 .

${ }^{54}$ Albæk, op. cit., note 51 above, p. 190.
}

${ }^{55}$ Vallgårda, op. cit., note 3 above, ch. 11. 


\section{Signild Vallgårda}

considered the biggest threat. Gay people were treated differently and in similar ways as in Denmark. A comparison of the development of HIV/AIDS policies in Sweden and Denmark demonstrates that the importance of paths, and which paths present themselves, depends on the nature of the problematization, or, in other words, on framing and agenda setting. 